\title{
What do you know about alternative energy? Development and use of a diagnostic instrument for upper secondary school science
}

\begin{abstract}
The need for renewable and non-fossil fuels is now recognised by nations throughout the world. Consequently, an understanding of alternative energy is needed both in schools and in everyday life-long learning situations. This study developed a two-tier instrument to diagnose students' understanding and alternative conceptions about alternative energy in terms of: sources of alternative energy, greenhouse gas emission, as well as advantages, and disadvantages. Results obtained with Year 10 and 11 students $(n=491)$ using the 12-item two-tier instrument $(\alpha=$ 0.61) showed that students' understanding of alternative energy was low $(\mathrm{M}=7.03 ; \mathrm{SD}=$ 3.90). The 23 alternative conceptions about alternative energy sources that could be identified from the instrument are reported. The implications for teaching and learning about alternative energy and suggestions for further development and improvement of the instrument are presented.
\end{abstract}

Keywords: Alternative energy; Environmental education; Alternative conceptions; Two-tier test items; Diagnostic assessment 


\section{Introduction}

The world's population is rapidly increasing causing a rise in the demand for energy use. Conventionally, the sources of energy used worldwide are coal, oil, and other fossil fuels such as natural gas. However, concerns about the depletion of these fossil fuels, particularly of oil, and their impact on the environment and sustainability is so huge that groups of countries have developed environmental protection policies, such as the Kyoto Protocol, to curb the contribution to global warming through Clean Development Mechanisms (CDM), carbon emission trading, and joint implementation (UNFCCC, 2011a). Consequently, many developed countries have pledged to reduce carbon emissions with the Kyoto Protocol as their guide. In addition, the Conference of the Parties (COP) was established in 2012 to put into effect a binding global climate treaty. Subsequently, this date was extended to 2020, to enable countries to make their commitment to reducing carbon emission more concrete. Strategies for targets to be met by 2050 for a sustainable future include cutting carbon emissions, reaching cap and trade agreements, and going carbon-neutral (UNFCCC, 2011b). A large part of these strategies to meet these targets are to utilise alternative energy sources.

The sources of energy that are alternative to fossil fuels, focused upon in this study, are renewable energy such as solar, hydropower, geothermal, wind, ocean energy and biomass energy. The non-renewable nuclear energy source and hydrogen fuel cells were also included in this study due to frequent references to these sources. The provision of electric power, transportation, and heating/cooling needs of the world had been suggested to be feasible from a combination of sources mainly from the wind, water, and the sun (WWS) with the other alternative energy sources - geothermal, hydropower, and ocean energy - filling in the gaps (Delucci \& Jacobson, 2010). However, a full conversion to WWS power worldwide is not recognised not due to technological or economic barriers but due to social and political barriers. In order to reduce and eliminate these social and political barriers, understanding of two main 
factors were considered to be important in this study. The first factor is how efficient these alternative energy sources are compared to each other and to fossil fuels. The second set of factors are what are the advantages and disadvantages of these alternative sources of energy, in particular, the amount of greenhouse gas emitted and the cost to produce these sources.

\section{Objectives of the Study}

Schools can play an important role in increasing understanding of alternative energy amongst students who will be the future generation of energy users and developers. The purpose of this study was to develop a two-tiered diagnostic instrument to identify conceptions and common alternative conceptions about each of the alternative energy sources (solar, hydropower, nuclear, geothermal, wind, chemical energy; ocean energy and biomass energy).

\section{Perspectives and Theoretical Framework}

Studies on energy have investigated understanding of energy as a whole, rather than of alternative energy sources. For example, a high percentage of lower sixth form students did not understand the key concepts of energy and little correlation has been found between their abilities in the application of qualitative knowledge and quantitative reasoning (Goldring \& Osbourne, 1994). Such "shallow learning" using quantitative variables can be avoided by developing knowledge and understanding of qualitative concepts (White, 1992). In order for understanding of concepts to be “deeper", students' understanding first needs to be elicited.

Students have been found to have alternative conceptions about many concepts, and these conceptions refer to students' inappropriate conceptions that are not in tandem the ones understood by the worldwide scientific community (Anderson, 2007). If these alternative conceptions are not challenged, they can interfere with the integration of new information, resulting in more deeply-held alternative conceptions (Duit \& Treagust, 2003; Duit, Treagust \& Widodo 2013). 
Many teaching and learning approaches that facilitate conceptual change (from alternative to scientifically acceptable conceptions) have been reviewed by Wenning (2008). In all these conceptual change approaches, the determination of students' alternative conceptions is the first step. This can be easily and efficiently ascertained and scored with the use of two-tier diagnostic tests (Treagust, 1988; Tsai \& Chou, 2002).

Many two-tier diagnostic instruments have been developed to determine understanding and alternative conceptions of concepts and principles in science among students due to their ease of use and efficiency in the determination of students' alternative conceptions. Some two-tier instruments that have been developed in the past are presented in the online supplementary material.

The two-tier diagnostic instruments consist of a first tier with the content part and a second tier with a reasoning part related to the content of the first tier. These two-tier diagnostic instruments have the advantage over one tier instruments as they test students' reasoning (Tamir, 1971) and afford a sensitive and effective way of assessing meaningful learning among students (Chandrasegaran, Treagust \& Mocerino, 2007) while providing the ability to gain insight into students' mental models more efficiently (McClary \& Bretz, 2012).

A determination of whether or not the concepts about alternative energy are understood adequately by students in their final year of secondary schools would be useful in order to help them contribute to society as future citizens. The information subsequently made available can assist teachers in their planning and conduct of lessons to enable students to understand these concepts. People in life-long learning situations can also use the instrument developed in this study as part of their determination of their understanding about alternative energy sources. 


\section{Studies on alternative conceptions about alternative energy sources}

Although there have been many studies on students' conceptions of energy, most did not involve alternative energy sources. Research on understanding and alternative conceptions of alternative energy sources has been mainly for policy-makers or for the general public.

Very little data are available pertaining to studies on students' conceptions of alternative energy sources. Table 1 lists the alternative conceptions about energy that are different from the traditional alternative conceptions about energy sources from fossil fuels.

Place Table 1 here

In terms of sources of energy, hydrogen fuel cells and nuclear energy have been mistaken to be renewable sources of energy (Romm, 2004). Limited versions or forms of the sources of energy seem to be understood, for example, the understanding that solar energy is limited to producing hot water only (Komm, 1995) or works only when there is direct sunlight (Oehmen, 2011). Similarly, views are held that hydropower is limited to water being stored behind a very large dam (Loo \& Loo, 2007).

The alternative conception that was prevalent seemed to be that the use of renewable energy sources would be insufficient to provide for the whole world's need for energy (Wilkenfield, Hamilton \& Saddler, 2007; Needham, 2008; Diesendorf, 2010). However, it has been claimed that with wind, water, and the sun (WWS) complemented by other alternative energy sources from geothermal, hydropower, and ocean power, it is possible to supply energy needed for the whole world (Delucci \& Jacobson, 2010).

In terms of emission of greenhouse gases, it seems that all or many of the renewable energy sources (hydrogen fuel cells, nuclear, and geothermal) were mistakenly understood to not produce any 
greenhouse gases when they are converted to usable energy (Ricker, 2008; Romm, 2004; Fleming, 2006, Wimer, LaMori \& Grant, 1977; Palmeri, 1993). In addition, students confused the greenhouse effect with the effect on the ozone layer (Boyes \& Stanisstreet, 1993; Boyes \& Stanisstreet, 1998; Hansen, 2010) and explanations for causes of global warming were varied (Niebert, Riemeier and Gropengiesser, 2013).

Other notable alternative conceptions arise from the misunderstanding that all renewable energy sources of energy do not cost anything (Wilkenfield, Hamilton \& Saddler, 2007; Needham, 2008; Diesendorf, 2010); that wind energy involved too much noise and killed too many birds; or that nuclear power plants are able to explode like an atomic bomb (Oehemen, 2011).

\section{Design of study}

The development of this instrument was made possible with the responses obtained from students in Brunei with the final validation of the instrument made with Year 10-11 students. Hence a brief description is provided to explain the background of Brunei's energy supply and consumption patterns, commitments to use of alternative energy as well as the curriculum that the students in Brunei had undergone.

\section{Background of Brunei}

Brunei, acceded to the United Nations Framework Convention on Climate Change in 2007 (UNFCCC, 2011c), and is moving towards the development of alternative energy sources. At present, Brunei is heavily dependent on oil and gas as energy sources. The production of energy, such as for electrical power in the country, is mainly (99.7\%) from natural gas (Mohammad Ali, 2013). The viability of using natural resources to produce renewable energy, such as solar energy, wind energy or hydropower, has been investigated, and moves to initiate the development of these alternative energies are being made. Alternative energy is seen as 
the key solution for future energy supplies and an attempt to address the potentially catastrophic effects of global climate change. Brunei exports most of the oil (7.29 Mt in 2011) and natural gas produced (0.54 Mt in 20011) (IEA, 2011).

The estimated population in Brunei was 414,400 in 2010 (BEBD, 2011). Brunei ranks high with the rest of the world in the human development index $\left(30^{\text {th }}\right)$ at 0.855 for 2012 (UNHDP, 2013), adult literacy rate $\left(38^{\text {th }}\right)$ at $92.67 \%$ (World Development Indicators database 2006), and in spending on education, $\left(6^{\text {th }}\right)$ at $9.1 \%$ of GDP spent (UNHDP, 2002). Students in Brunei take the Brunei-Cambridge General Certificate of Education Ordinary level (B-C GCE O level) examination (at upper secondary level usually at Year 11); and the Brunei-Cambridge General Certificate of Education Advanced level (BC-GCE A) examination, which equates to UK GCE Advanced standard (at pre-university level, usually at Year 13) (UCAS, 2013). Brunei also ranks high in comparative education quality standards: Primary education $\left(20^{\text {th }}\right)$; Educational system $\left(25^{\text {th }}\right)$; Quality of mathematics and science education $\left(23^{\text {rd }}\right)$; Higher education and training $(57 \%)$ (Schwab, 2013). However, this emphasis on education in Brunei may not be reflected in the consideration for sustainable use of energy. Brunei's carbon emission is miniscule compared to the rest of the world at 8.27 million metric tons of carbon dioxide $\left(\mathrm{CO}_{2}\right)$ in 2010 , but Brunei ranks high in electrical power consumption per capita, $20^{\text {th }}$ out of 121 countries at $7,615 \mathrm{kWh}$ per capita (World Development Indicators database 2004).

For the Brunei Year 10 and 11 science syllabus, reference to alternative energy sources can be considered superficial and is not covered in depth. The content from the Years 10 and 11 Brunei syllabus and the comparison with the American Association for the Advancement of Science (AAAS) Strand Maps (2014) are shown in Table 2.

Place Table 2 here 
It appears that the science curriculum from the AAAS strand maps for Energy Resources dealt with these three areas of study: the finiteness of the resources for energy; the limiting factors of costs of obtaining energy; and the environmental consequences of different ways to obtain, transform and distribute energy at US Grades 6-8 (Brunei Year 6-8). In Brunei these principles are dealt with in isolation and usually at the Years 10-11 levels.

\section{Methodology}

Qualitative and quantitative methods were utilised in this study, involving a sample of 491 Year 10 and 11 students. These students were from low, middle and high ability groupings from 28 out of the 34 government secondary schools in Brunei Darussalam. The education for the subjects science, mathematics and geography are conducted in the English medium from Year 4 to Year 13, hence students' ability in English should be adequate to respond to the items in the instrument. The instrument was administered to the students in half-hour sessions at their school locations in specially arranged sessions.

\section{Instrument development and validation}

The development and validation of the instrument were guided with the process initiated by Treagust (1988) and involved repeated cycles of three broad steps: defining the content, obtaining information about students' conceptions, and developing the diagnostic instrument.

\section{Defining the content}

The content for alternative energy involved the review of the school syllabus, textbooks and reliable internet sources to identify those concepts that needed to be understood as well as common alternative conceptions found from the literature. Initially 123 propositional content 
knowledge statements about alternative energy were derived from textbooks and reliable internet sources by two Physics education academics. They identified key information about the nature of the source of the alternative energy and any details they could put together about each of the alternative energy sources. These propositional content knowledge statements were then verified by three Science education academics. Refining of the propositional content knowledge statements to ensure accuracy and the use of correct grammar was made during the verification process. These 123 propositional content knowledge statements were then independently content-validated by an expert panel made up of another four tertiary Physics university academics, working separately. Based on their feedback as to whether or not the responses and elements of the questions were reasonable or accurate, several of the propositional content knowledge statements were edited or eliminated. After two further cycles of refining the propositional content knowledge statements by the Science education researchers, the remaining 47 propositional statements (see Figure 1) constituted the concepts and principles for alternative energy that were used in this study. Duplications were identified and eliminated and statements were rephrased so that unambiguous meanings were achieved as much as possible. These revised 47 propositional content knowledge statements were sent again to a Physics academic who proposed refinements to the statements to ensure accuracy.

[Figure 1 about here]

The correct conceptions for alternative energy used in this study listed in Figure 1 were categorised into the following categories: Sources of alternative energy; Energy conversion in generating power; Greenhouse gas emissions for each of the alternative energy sources; Costs of the production of power as well as their advantages and disadvantages. Hence, content validity was conducted to ensure that the content was accurate, within the boundaries of the area of study and is appropriate for the Years 10 and 11 students. 
Obtaining information about students' conceptions

To investigate possible alternative conceptions about alternative energy sources, distractors for the second tier (reasoning part) of the items were obtained using the following methods. Firstly, common alternative conceptions already identified in the literature (see Table 1) were incorporated in the first draft of the instrument. An example of an item in the first draft of the instrument is illustrated in Figure 2.

[Figure 2 about here]

Secondly, open-ended responses of students for the reasoning part of the instrument in the first pilot study (administered to 39 Year 10 students in the age group between 13 to 16 years old) were categorised. An example of an item in the second draft of the instrument is found in Figure 2. Similar meaning responses of students' for each test item were analysed and grouped together. Each item was then rewritten to include possible non-targeted responses from the students as well as from the literature review. An open-ended option (option E) was also made available for students to provide their own ideas other than the provided distractors. If there appeared to be commonly found reasons (mentioned more than twice), then these were utilised as distractors in the second tier of the items for the third draft of the instrument. For example, students' pre-conceived idea that solar thermal energy needs light energy but not heat energy in order to generate electricity was incorporated in item 7.

\section{Developing the diagnostic instrument}

This stage involved three cycles of designing and redesigning of the test items. In each cycle, the third, fourth and fifth drafts of the test items in the instrument were piloted by administering the 
draft instruments with Year 10 students $(n=68)$, Year 13 students $(n=61)$ and undergraduate students in the age group between 20 to 25 years old $(n=61)$, consecutively. In between these pilot studies, the items were analysed and edited to ensure that the questions read well and were demanding appropriate levels of reading, as well as content validated by the researchers and academics in Physics education and English education. Comments were made on the items in the tests to correct the terms, wording and accuracy. Inter-rater agreement obtained with the two academics averaged 0.9. Analyses of the pilot results obtained provided guidance on items that were either too easy or difficult and about the adequacy of the internal reliability of the draft test instruments. With the results obtained from the pilot studies, the items in the test were refined. Revisions to the items were made to make the questions clearer and eliminate ambiguous distractors.

Lastly the final version of the 20-item two-tier multiple-choice diagnostic instrument ("What do you know about alternative energy?" was used in this study. The final instrument was administered to 491 students $($ female $=277$; male $=214)$ from Year $10(\mathrm{n}=268)$ and Year $11(\mathrm{n}$ =223) with ages ranging from 15 to 19 years. The content covered for each type of alternative energy source was categorised into (i) sources of the energy, (ii) conversion of energy in generation of electricity and efficiency of energy from power plants, (iii) greenhouse emission, (iv) costs of electricity generation, and (v) disadvantages and advantages of these alternative energy sources (see Table 3). These categories formed the specification grid for the diagnostic instrument after ensuring the propositional content knowledge statements were related to the concepts involved.

[Table 3 about here] 
Examples of items in the diagnostic instrument "What do you know about alternative energy?" are shown in Figure 3.

[Figure 3 about here]

\section{Analysis procedures}

\section{Statistical Analysis of the "What do you know about alternative energy?" diagnostic instrument}

The responses of the 491students to the 20 items in the "What do you know about alternative energy?" were analysed using a SPSS statistics software program.

\section{Data Screening}

The data was screened for univariate outliers. Fifteen out-of-range values, due to administrative errors, were identified and recoded as missing data. The minimum amount of data for factor analysis was satisfied, with a final sample size of 491 (using listwise deletion), providing a ratio of over 37 cases per variable (Comfrey \& Lee, 1992).

\section{Sample characteristics}

A Shapiro-Wilk's test $(\mathrm{p}>0.05)$ (Shapiro \& Wilk, 1965) and a visual inspection of their histograms, normal Q-Q plots and box plots showed that the scores were approximately normally distributed for both males and females, with a skewness of $0.531(\mathrm{SE}=0.165) ; 0.472(\mathrm{SE}=0.144)$ and Kurtosis of $0.456(\mathrm{SE}=0.328) ; 0.054(\mathrm{SE}=0.287)$ for the males and females, respectively (Howitt \& Cramer, 2011). 


\section{Factor analyses for the instrument}

Principal components analysis was used to determine if the five categories originally used show up in the factorial analyses. Kaiser-Meyer-Olkin Measure of sampling adequacy obtained was 0.746 providing confidence that component analyses should be performed; Bartlett's Test of Sphericity showed statistically significant correlations beyond 0.000 . Solutions for three factors were each examined using oblimin rotations of the factor loading matrix. The three factor solution only explained $37 \%$ of the variance.

Only 13 items contributed to a simple factor structure and met the minimum criteria of having a primary factor loading of 0.4 or above, and no cross-loading of 0.3 or above. Five items met the minimum primary factor loading criteria but not for cross loading of 0.3 or below. Item 10 did not contribute to a simple factor structure and failed to meet the minimum criteria and was eliminated from the scales used for analyses. The three categories derived from the factorial analyses performed could be labelled as: "Sources of alternative energy" $(\alpha=0.61$, no of items $=$

5; Items 5, 1, 4, 19, 11, 20; factor loadings ranging from 0.641 to 0.541 ); "Consequences of utilisation of alternative energy" $(\alpha=0.241$, no of items $=3$; Items no 12,3 and 14 , with factor loadings ranging from 0.721 to 0.413$)$; "Process to consider about alternative energy" ( $\alpha=$ 0.241, no of items = 3 Items 13,18 , and 9; factor loadings ranging from 0.646 to 0.457 ). However, although the Cronbach's alpha for the scale, "Sources of alternative energy" $(\alpha=0.61$, no of items $=5$ ) was acceptable, the other two scales did not present acceptable internal reliability. These three factors, derived from factorial analyses, did not fit the original a 'priori' categories for the instrument. However, the Cronbach's alpha reliability coefficient $(\alpha)$ of 0.4 for the 20 items instrument was not satisfactory as well. Hence, the 12-item instrument, which contributed to the simple factor structure and internal reliability of Cronbach's alpha ( $\alpha=0.61$ ), was utilised for reporting of the results of the instrument "What do you know about alternative energy?" 


\section{Item analyses}

In addition, students' responses were used to determine the final test instrument reading difficulty according to Fry's readability graph (Fry, 1977). Students' responses were allocated one mark for each tier correct answer. Mean scores and percentages of correctly answered items for the content part, reason part and for both parts (content and reason) of the items were determined. Alternative conceptions in the topic were considered commonly found if more than $10 \%$ of the students' responded to the items wrongly (Gilbert, 1977) and a list of the common alternative conceptions for alternative energy was produced.

\section{Results and Discussion}

Features of the revised "What do you know about alternative energy?" instrument

The final instrument test statistics are reported in Table 4. The Cronbach's alpha reliability coefficient $(\alpha)$ for the 12-item instrument after deleting eight items $(2,6,7,8,13,15,16$, and 17) was 0.61 when both parts of each item were scored together (see Table 4). Consequently, only 12 out of the original 20 items of the instrument were retained and used in the following analyses. The reliability (internal consistency) of the 12-item questionnaire of 0.61 , is minimally acceptable (DeVellis, 1991) or moderate for multiple choice content tests (Nunnally, 1978) or acceptable (Adams \& Wieman, 2011; George \& Mallery, 2003) for research purposes. The internal reliability (Cronbach's alpha coefficient) for the test was low possibly due to the wide nature of the area of study of the instrument and that most students' conceptions of alternative energy are not coherent. The utilisation of the 12 items instead of the original 20 items in the test had minimum impact on the content validity. Only one of the original categories, conversion of energy in generating electricity and efficiency was eliminated (see Table 3). The other categories were affected by having reduced number of items.

Based on Fry's readability graph, out of the final 12 items used for these analyses, more 
than half $(n=9)$ were at a reading grade level of between Years 7-10 and three items were above reading level of Year 10. For students who use English as a second language, the Year 10 reading level may still be too high; hence, simplification of these items is still needed.

\section{Students' understanding of alternative energy}

The students' scores on the content, reasons, and content with reason components of the items are summarised in Table 4. The understanding of the students about alternative energy sources using the "What do you know about alternative energy?" instrument was found to be very low, with a mean score of 7.03 out of a possible of 24 . The standard deviation for the mean score of the students in the test was 3.90 .

[Table 4 about here]

Figure 4 illustrates the results for the students, with the percentage of students who responded correctly as the ordinate and item number as the abscissa. The highest percentage of correct responses achieved by the students were $41 \%, 43 \%$ and $36.3 \%$ for the content part (first tier), reason part (second tier), and the content and reason part (both tiers), respectively. The performance of the students in the content part was higher than the reason part for some items only (items 10, 12, and 20). For the reason part, the students performed better in the rest of the items except for item18, where both the content and the reason responses were almost equal. Nevertheless, the performance for the combination of the first tier and the second tier for all the items were less than either the content or the reason part of the items, and the understanding of the students about alternative energy sources seems to be very low.

[Figure 4 about here] 


\section{Alternative conceptions about alternative energy sources identified by the revised instrument "What do you know about alternative energy?"}

The content part of the items contains three distracters with one choice of "I don't know" and one correct answer. Meanwhile, the reason part of the items contains three distracters with one choice of "Please state your own reason" and one correct answer. Hence the possible alternative conceptions from the content, reason and the combination of both content and reason for the 12 items of the instrument are 36, 36 and 108, respectively. Twenty-three alternative conceptions about alternative energy sources were found from the instrument used in this study. These alternative conceptions are listed in Table 5.

[Table 5 about here]

\section{Sources of energy}

The source of energy that can be obtained from the interior of the earth was identified wrongly as solar energy (by $40 \%$ students) instead of geothermal energy. Meanwhile the reason given for this was that all heat necessarily comes from the sun (32\%). This choice could be due to many textbooks stating that all energy is produced by the sun and the limited scope of knowledge on the various sources of alternative energy held by the students.

Uranium was wrongly thought to be found in pure form (25\%) and to be obtained directly from the ground (15\%). Uranium needed for this form of energy source exists at very low concentrations in uranium ores and there are very few reserves known. In addition, these ores need to be processed after being mined using open cut or underground techniques in the ground (Diesendorf \& Christoff, 2006). Uranium is also mistakenly thought to be renewable and that it is plentifully available (12\%) even though the Uranium 235 needed for nuclear energy actually constitutes only $0.7 \%$ of the natural uranium (Diesendorf \& Christoff, 2006)

A hydrogen fuel cell was thought to be a clean form of energy and the reason associated 
with this is that the production of hydrogen does not produce any greenhouse gases $(38 \%)$. However, most hydrogen needed for the fuel cells are produced by steam-reforming of natural gas or by electrolysis, and this process emits carbon dioxide (Hinrichs \& Kleinbach, 2006). Hydrogen was thought of as the by-product of the hydrogen fuel cell (15\%), when actually water is the by-product (Romm, 2004).

Nuclear energy was incorrectly believed $(26 \%)$ to be produced by nuclear fusion or nuclear explosions (20\%) instead of nuclear fission. Nuclear fission is the process used for production of nuclear energy with the breakdown of uranium into particles of other elements to release a lot of energy. Further, perhaps due to the association with the word fusion, uranium was thought to be combined and converted into nuclear energy (18\%). It is not surprising that $23 \%$ of the students did not know how nuclear energy is produced. The alternative conception that nuclear energy is produced in nuclear explosions found in this study is similar to that found by Oehemen (2011).

\section{Greenhouse gas emission}

The concern for the emission of greenhouse gases from the production of energy from fossil fuels has resulted in efforts to move away from it. Hence an understanding of whether similar amounts of greenhouse gases are emitted from the energy generation from alternative energy sources would provide ideas on whether to use these alternative energy. Many students did not understand that greenhouse gases could be emitted at any stage of the life cycle of any energy generation. These stages include exploration, mining, transport of the fuel, waste management and disposal, as well as power generation (Spadaro, Langlois \& Hamilton, 2000). Instead, greenhouse gases were misunderstood to be emitted during mining, processing and transportation only (22\%), or during construction and decommissioning of power plants only (27\%), or during the generation of electrical power (18\%). Only $20 \%$ of the students correctly 
answered that greenhouse gases are emitted in all the three processes (Spadaro, Langlois \& Hamilton, 2000).

The contribution to global warming is less through production of greenhouse emission from any stage of energy generation from all alternative energy sources than that from energy generated from fossil fuels (Morgil, Secken, Yucel, Ozyalcin-Oskay, Yavuz, \& Ural, 2006) and this was understood by $37 \%$ of the students. However, the reasoning that alternative energy sources release less greenhouse gases compared to fossil fuels since less carbon-based fuels are used was less understood (20\%). On the other hand, it was assumed that none of the alternative sources of energy contribute to global warming (17\%) or only hydrogen fuel cells contribute to global warming (11\%). Further, all alternative sources of energy were also thought to contribute to global warming to the same proportion as fossil fuels (13\%). As technology capacity improves this could very well be true in the future (Weisser, undated).

The emission of greenhouse gases needs to be considered throughout the whole life cycle of the process of power generation, starting from extraction of its source to the generation of electricity (Evans, Strezov \& Evans, 2009). The life cycle of the emission of greenhouse gases was correctly understood to be highest with biomass (16\%). However, nuclear energy (35\%) and solar power energy (17\%) were wrongly thought to be highest emitters of greenhouse gases. There was also misunderstanding that all biodiesels would emit less greenhouse gases than diesel (30\%), and this was attributed to all biodiesels containing less carbon molecules compared to diesel (23\%). The generation of greenhouse gas to produce biofuel depends on whether the raw material is derived from rainforests and peatlands (in which case the emissions are more) or from plantations (Danielsen et al., 2008). 


\section{Cost (construction and electricity)}

In terms of the costs for construction of power plants between the four alternative sources of energy - ocean thermal, wave, hydropower and tidal power - ocean thermal costs are the highest because they require a lot more infrastructure (Open EI, 2012). However, the misunderstanding that power plant construction costs are the highest for hydropower (43\%) was because a large dam needs to be built (25\%). Another misunderstanding was that plant construction costs were highest for tidal power (13\%). This view could be due to more references to costs of electricity generation per unit of megawatt hour (Open EI, 2012) rather than of construction of power plants and very little information for ocean thermal power generation. Only costs of more common forms of alternative energies are being calculated and projected (USEIA, 2013).

\section{Advantages and disadvantages of alternative energy}

Other considerations aside from greenhouse gas emission, are cost and whether the source can be accessed easily in an area include matters such as whether or not the generation of energy from these alternative energy sources would be detrimental to the environment or for human survival. Wind energy power generation is often misunderstood and confused. Wind power plants produce noise up to only 300 metres and the sound level is about $40 \mathrm{~dB}$, which is an acceptable sound level in any country. Wind turbines do not kill a lot of birds but do kill less than two birds per turbine per year (Mathew, 2006). However, the killing of birds (31\%) or noise pollution (14\%) was considered to be not true. Wind power plants could be located offshore as well as onshore (Mathew, 2006). However, the location of wind power seems to be misunderstood to be located only onshore in combination with wind power plants not killing birds and not producing noise $(20 \%)$.

In terms of competition for food, solar energy (21\%) and ocean thermal energy (16\%) are mistakenly thought to be competing with humans for food. Biomass energy sources generation would compete with humans for food as the harnessing from plantations requires a lot of land 
that could otherwise be used for food generation (EIA, 2009; McDonald, Fargione, Kiesecker, Miller, \& Powell, 2009; Melillo et al., 2009). Meanwhile the reason for solar energy to compete for food with humans seems to arise from the point usually stated that the sun is the main source of energy for most organisms.

Regarding the safe disposal of waste generated from the use of alternative energy, fuel cells are mistakenly thought to be more difficult to dispose of safely (16\%) than the other forms of alternative energy and this is attributed to the reason that the waste generated from fuel cell requires hundreds of years to decompose. It takes thousands of years for nuclear energy waste to decay to safe levels (World Nuclear Association, 2009).

\section{Conclusions and Implications for Science Education}

The instrument "What do you know about alternative energy?" was developed and evaluated to provide an idea if it is suitable for utilisation by teachers to elicit alternative concepts in students and to determine the level of understanding of alternative energy sources. In addition, the understanding and common alternative conceptions about alternative energy were identified in order that these could be highlighted and addressed in the planning of teaching and learning about alternative energy sources.

\section{“What do you know about alternative energy?" instrument}

The 12 item two-tier diagnostic instrument "What do you know about alternative energy?" was shown to be a viable and useful instrument to determine students' understanding of alternative energy sources and the common alternative conceptions about alternative energy that need to be addressed. However, improvements in the "What do you know about alternative energy?" instrument could be made. This could be done if some of the items that were deleted (8 out of 20 original items) were reworded to determine correct conceptions or by simplifying the 
items that are of reading levels more than Year 10 (Items 5, 6, 9, 12, 13) for better readability. The rewording of some of the deleted items would have made these useable. For example, the term 'chemical' needed to be changed to 'nuclear' for the energy conversions in a nuclear power plant (Item 6). The distractor referring to the sun as the main source of energy (in item 19) or heat necessary comes from the sun (item 1) is too general and seems to have led students to favour this as an answer, so it needs to be replaced with less ambiguous and more specific distracters. In item 13 it is possible that students did not know the meaning of the phrase "remediation of waste" in one of the distractors. Hence the word "remediation" could be replaced with simpler words such as "methods to reverse environmental damage".

Item 10 investigated the extent to which alternative energy contributed to global energy needs and was found to be an outlier using direct oblimin rotation solution for factorial analyses. The wording in item 10 focused on global warming rather than greenhouse gas emission. Hence a revision of item 10 to focus on greenhouse gas emission rather than global warming could be considered instead.

Although the factorial analyses produced three possible factors, the internal reliabilities for two of the scales were not acceptable so these two factors could be strengthened through rewriting or changing the items (Items 12, 3, 14 for one factor and items 13,18, 9 for another factor).

The results from the administration of this instrument are different from other many two-tier tests, in that the students' achievement was not always higher with the content part of the items (first tier) compared with the reason part of the items (second tier). This possibly shows that there was limited content knowledge of the topic. However, generally, with both parts of the items (content and reasons), the results are lower than either the content or the reasoning part of the items. This finding could mean that the students responded to the items without much understanding based on rote learning or that this area of study is covered in lessons 
superficially.

\section{The implications for teaching and learning about alternative energy sources}

An updated version of the instrument could be utilised with students from various countries to increase the instrument's validity and reliability. The test instrument designed, with further improvement suggested from this study, could be used prior to formal instruction so that teaching plans and strategies could be modified to address identified alternative conceptions. The use of the instrument is particularly helpful if teachers and researchers are unaware of students' conceptions and how to incorporate the conceptions of alternative energy sources in the teaching process. If alternative conceptions or misunderstandings are identified, remedial action could be taken immediately, before they become too deeply entrenched in the students' cognitive frameworks. The instrument could also be used to evaluate students' understanding after formal instruction, as well as to help teachers prepare for courses on alternative energy.

Using this instrument, Years 10 and 11 Bruneian students' understanding of alternative energy was found to be low. The results of this study drew attention to the strengths and weaknesses of the curriculum that the students follow, and the need for educators to highlight those concepts that are best understood and which need to receive more emphasis. For example, the students' understanding of costs of construction for electricity generation is poor. This could point to the limited attention given to the economics of electricity generation in the education of the students. A search in the Science curricula (UCLES, 2007a, 2007b, 2007c, 2010) showed that the content part did not cover the topic for costs of alternative energy. Conversely, in the assessment objectives of the economics syllabus Y10-11 (UCLES, 2010), students are supposed to be able to evaluate the social and environmental implications of particular courses of economic action. For students taking science subjects but not economics, the aspects of costs for alternative energy may not be dealt with. Information concerning the various forms of alternative energy and the important features, needed for decision making, such as costs 
and the greenhouse gas emissions, were difficult to obtain and only recently made transparent and easier to compare with the emergence of new databases which compare costs (Open EI, 2012) and greenhouse gas emissions (Weisser, undated). Hence it not surprising to find out from this study that knowledge and understanding about various forms of alternative energy sources is limited.

The understanding of alternative energy involves understanding the science of energy production, economics (costs and benefits), and effects of power generation on the environment. In effect, an interdisciplinary approach to the teaching and learning of the area of alternative energy needs to be used to promote better understanding of the topic. Although suggestions for alternative energy education have been made in the past (Scott, 1980), such as for nuclear energy, this does not seem to have occurred.

This study provided evidence that Year 10 and 11 students in Brunei hold several common alternative conceptions about alternative energy. Perhaps this is not altogether surprising given the country's dependence on fossil fuels and despite the current need for emphases of alternative energy in the curriculum. With enhanced understanding, important decisions concerning the type of alternative energy for future power generation in the country could have less chance of being based on poor understanding.

Further studies using improved versions of this instrument could be carried out with other students in different levels, with teachers as well as with members of the public. Similar instruments developed specifically for each type of alternative energy such as solar energy, hydropower and wind would promote better understanding of the details of each of the sources of energy. 


\section{References}

Adams, W.K. \& Wieman, C.E. (2010). Development and validation of instruments to measure learning of expert-like thinking. International Journal of Science Education, 33(9), $1289-1312$

Anderson, C.W. (2007). Perspectives on science learning. In S.K. Abell \& N.G. Lederman (Eds.), Handbook of research on science education (pp. 3-30). Mahwah, NJ: Erlbaum.

Baird, S. (1994). Hydro-electric power. Retrieved from http://www.physics.ohio-state.edu/ kagan/phy367/P367_articles/HydroElectric/hydroelectri c.html

BEBD (Department of Economic Planning and Development) (2011). Brunei Darussalam Key Indicators. Prime Minister's Office. Brunei Darussalam.

Boylan, C. (2008). Exploring elementary students' understanding of energy and climate change. International Electronic Journal of Elementary Education, 1(1), 1-15.

Boyle, G. (1996). Renewable energy: Power for a sustainable future. Oxford: Oxford University Press.

Bratley, J. (2007). What is geothermal energy? Retrieved from http://ezinearticles.com/?What-Is-Geothermal-Energy\&id=478867

Breeze, P. (2005). Power generation technologies. Oxford: Elsevier.

Comfrey, A. L., \& Lee, H. B. (1992). A First Course in Factor Analysis. Hillsdale, NJ: Lawrence Erlbaum Associates.

Cowan, G. A., \& Adler, H. H. (1976). The variability of the natural abundance of ${ }^{235}$ U. Geochimica et Cosmochimica Acta, 40(12), 1487-1490.

Danielsen, F., Beukema, H., Burgess, N.D., Parish, F., Brühl, C.A., Donald, P.F., Fitzherbert, E.B. (2008). Biofuel plantations on forested lands: Double jeopardy for biodiversity and climate, Conservation Biology, pp. 1-11.

DeVellis, R.F. (1991). Scale development. Newbury Park, NJ: Sage Publications.

Diesendorf, M. (2010). Myths, fallacies and 'spin' about greenhouse solutions. Retrieved from http://www.energyscience.org.au/BP21 Myths v3.pdf\#

Diesendorf, M. \& Christoff, P. (2006). CO2 emissions from the nuclear fuel cycle. Retrieved from http://energyscience.org.au/FS02\%20CO2\%20Emissions.pdf

Duit, R., \& Treagust, D.F. (2003). Conceptual change: A powerful framework for improving science teaching and learning. International Journal of Science Education, 25(6), 671-688.

Duit, R. Treagust, D. F, \& Widodo, (2013). Teaching science for conceptual change: Theory and practice. S. Vosniadou (Ed.). International handbook of research on conceptual change (pp. 487-503). New York: Routledge.

Duncan, T., \& Kennett, H. (2009). GCSE Physics . London: John Murray Ltd.

(EIA) U.S. Energy Information Administration. (2009). International energy outlook 2009. DOE/EIA-0484(2009). Washington, DC. Retrieved from http://www.eia.doe.gov/oiaf/ieo/index.html.

(EIA) U.S Energy Information Administration (2010). Updated Capital Cost Estimates for Electricity Generation Plants. Retrieved from http://ftp.eia.doe.gov/forecasting/updatedplantcosts.pdf

(EIA) U.S. Energy Information Administration (2011). Brunei: Overview/Data. Retrieved from 
http://205.254.135.7/countries/country-data.cfm?fips=BX

Energy Alternatives. (2007). Solar photovoltaic (PV). Retrieved from http://www.energyalternatives.ca/content/Categories/SolarPVInfo.asp

Evans, A., Strezov, V., \& Evans, T. (2009). Assessment of sustainability indicators for renewable energy technologies, Renewable and Sustainable Energy Reviews, 13(5), 1082-1088.

Fleming, D. (2007). The lean guide to Nuclear energy: A life cycle in trouble. London: The Lean Economy Connection.

Fry, E. (1977). Fry's readability graph. Journal of Reading, 20, 242-252.

George, D., \& Mallery, P. (2003). SPSS for windows step by step: A simple guide and reference. 11.0 update (4th ed.). Boston, MA: Allyn \& Bacon.

Gilbert, J.K. (1977). The study of student misunderstandings in the physical sciences. Research in Science Education, 7(1), 165-171.

Goldring, G., \& Osborne, J. (1994). Students' difficulties with energy and related concepts. Physics Education, 29(1), 26-32.

Hansen, P. K J (2010) Knowledge about the greenhouse effect and the effects of the ozone layer among Norwegian pupils finishing compulsory education in 1989, 1993, and 2005-what now?, International Journal of Science Education, 32:3, 397-419, DOI: 10.1080/09500690802600787

Hinrichs, A. R., Kleinbach, M. (2006). Energy: Its Use and the Environment (Fourth Edition). Thomson Brooks/Cole. United State of America

Howitt D, Cramer D (2011).Introduction to SPSS Statistics in Psychology. Essex:Pearson Education Ltd

Komp, R.J. (1995). Practical photovoltaics: Electricity from solar cells (3rd ed.). Ann Arbor, MI: AATEC.

Loo, W.Y., \& Loo, K.W. (2007). Physics insights 2. Singapore: Pearson Education South Asia Pte Ltd.

Lu, L., \& Yang, H.X. (2010). Environmental payback time analysis of a roof-mounted building-integrated photovoltaic (BIPV) system in Hong Kong. Applied Energy, 87, 3625-3631.

Masutani, S.M., \& Takahashi, P.L. (2001). Ocean thermal energy conversion (OTEC). Retrieved from http://curry.eas.gatech.edu/Courses/6140/ency/Chapter2/Ency_Oceans/OTEC.pdf

Mathew, S. (2006). Wind energy: Fundamentals, resource analysis and economics. Netherlands: Springer.

McDonald, R.I., Fargione, J., Kiesecker, J., Miller, W.M., \& Powell, J. (2009). Energy sprawl or energy efficiency: Climate policy impacts on natural habitat for the United States of America. PLoS ONE, 4(8), 1-11.

Melillo, J.M., Reilly, J.M., Kicklighter, D.W., Gurgel, A.C., Cronin, T.W., Paltsev, S., \& Schlosser, C.A. (2009). Indirect emissions from biofuels: How important? Science, 3(26), 1397-1399.

Mohammad Ali, A.S.H. (2013), Brunei Darussalam Country Report. In Kimura, S. (ed.), Analysis on Energy Saving Potential in East Asia, ERIA Research Project Report 2012-19, pp.83-97.ERIA [online]. Available at: http:/www.eria.org/RPR_FY2012_No.19_Chapter_3.pdf

Moreira, R.J., \& Poole, D.A. (1993). In L. Burnham (Ed.). Renewable energy: Sources for fuels and electricity (pp.73-119). Washington, DC: Island Press.

Morgil, I., Secken, N., Yucel, A.S., Ozyalcin-Oskay O., Yavuz, S., \& Ural, E. (2006). Developing a renewable energy awareness scale for pre-service chemistry teachers. Turkish online 
Journal of Distance Education, 7(1), 63-74.

National Research Council. (2007). Environmental impacts of wind-energy projects. Retreived from http://www.nap.edu/catalog/11935.html

(NSDL) National Science Digital Library. NDSL Science Literacy Maps: Helping teachers to connect concepts, standards, and NSDL resources. American Association for the Advancement of Science (AAAS) Project 2061. The design world: Energy Resources. Retrieved from: http://strandmaps.nsdl.org/?id=SMS-MAP-2246

Needham, S. (2008). The potential for renewable energy to provide baseload power in Australia. Parliamentary Library: Information, analysis and advice for the Parliament, 9, 1-35.

Niebert, K., Riemeier, T \& Gropengiesser, H. (2103, September). The hidden hand that shapes conceptual understanding: choosing effective representations for teaching climate change. Paper presented at the symposium "Learning Biology with Multiple External Representations" at the biannual meeting of the European Science Education Research Association, Nicosia, Cyprus.

Nunnally, J.C. (1978). Psychometric theory (2nd ed.). New York, NY: McGraw-Hill.

Nussbaum, R. (2009). Childhood leukemia and cancers near German nuclear reactor: Significance, context and ramifications of recent studies. International Journal of Occupational Environmental Health, 15(3), 318-323.

Oehmen, J. (2011). Fukushima nuclear accident: A simple and accurate explanation. Retrieved from http://mitnse.com/2011/03/13/modified-version-of-original-post

(Open EI) OpenEI Transparent Cost Database. (2012) Retrieved from http://en.openei.org/apps/TCDB/

Palmerini, G.C. (1993). Geothermal energy. In L. Burnham (Ed.), Renewabale energy: Sources for fuels and electricity. (pp. 549-591). Washington, DC: Island Press.

Ricker, C. (2008). Is solar thermal power the answer? Retrieved from http://www.photonics.com/Article.aspx?AID=34306

Romm, J.J. (2004). The hype about hydrogen: Fact and fiction in the race to save the climate. Washington, DC: Island Press.

Schwab, K. (Ed.) World Economic Forum (2013). The Global Competitiveness Report $2012-$ 2013.

Retrieved from http://www3.weforum.org/docs/WEF GlobalCompetitivenessReport 2012-13.pdf

Scott, W. (1980). Nuclear power and the science curriculum. Physics Education, 15, 286-288.

Shapiro, S. S.; Wilk, M. B.(1965). An analysis of variance test for normality (complete samples). Biometrika, 52 (3-4): 591-611.

Sklar, S., \& Sheinkopf, K. (1991). Consumer guide to solar energy. Chicago, IL: Bonus Books, Inc.

Spadaro, V.J., Langlois, L., \& Hamilton, B. (2000). Greenhouse gas emissions of electricity generation chains: Assessing the difference. IAEA Bulletin, 42(2), 19-28.

ThinkQuest. (2001). Alternative energy. Retrieved from http://library.thinkquest.org/C0111401/alternative_energy.htm

Treagust D.F., (1988), Development and use of diagnostic tests to evaluate students' misconceptions in science, International Journal of Science Education, 10, 159-169.

Tsai, C.C., \& Chou, C. (2002). Diagnosing students' alternative conceptions in science. Journal of Computer Assisted Learning, 18, 157-165.

(UCAS) Universities and Colleges Admission Service. (2013). International examination results July 2013. Retrieved from http://www.ucas.com/sites/default/files/international-examination-result-dates-july-2013. 
pdf

Ueda, Y., Kurokawa, K., Kitamura, K., Yokota, M., Akanuma, K., \& Sugihara, H. (2009). Performance analysis of various system configurations on grid-connected residential PV systems. Solar Energy Materials and Solar Cells, 9(6-7), 945-949.

(UCLES) University of Cambridge Local Examinations Syndicate. (2007a). International general certificate of secondary education - Combined science 0653 syllabus: For examination in June and November 2009. Retrieved from http://www.pathways.ac.in/science/combinedscience2009.pdf

(UCLES) University of Cambridge Local Examinations Syndicate. (2007b). International general certificate of secondary education - Geography 0460 syllabus: For examination in June and November 2010. Retrieved from http://www.cie.org.uk/docs/dynamic/24687.pdf

(UCLES) University of Cambridge Local Examinations Syndicate. (2007c). International general certificate of secondary education - Physics 0625 syllabus: For examination in June and November 2009. Retrieved from http://www.cie.org.uk/docs/dynamic/5129.pdf

(UCLES) University of Cambridge Local Examinations Syndicate. (2010). General certificate of ordinary level (2010) - Economics syllabus 2281. Retrieved from http://www.cie.org.uk/qualifications/academic/middlesec/olevel/subject?assdef_id=906

(UNFCCC) United Nations for Framework Convention on Climate Change. (2011a). The UNFCCC in Cancun, COP16 / CMP 6, 29Nov-10Dec 2010. Retrieved from http://unfccc.int/meetings/cop_16/items/5571.php

(UNFCCC) United Nations for Framework Convention on Climate Change. (2011b). Kyoto Protocol. Retrieved from http://unfccc.int/kyoto_protocol/items/2830.php

(UNFCCC) United Nations for Framework Convention on Climate Change. (2011c). Status of ratification of the Convention. Retrieved from http://unfccc.int/essential_background/convention/status_of_ratification/items/2631.php

(UNHDP) United Nations Human Development Programme (2002). Education spending (\% of GDP) by country. Retrieved from http://www.NationMaster.com/graph/edu_edu_spe-education-spending-of-gdp

(UNHDP) United Nations Human Development Programme (2013). Human Development Report 2013 The Rise of the South:Human Progress in a Diverse World. Retrieved from http://hdr.undp.org/sites/default/files/reports/14/hdr2013_en_complete.pdf

(USEIA) U.S. Energy Information Administration, (2013) Annual Energy Outlook 2013, December 2012, DOE/EIA-0383(2012) Retrieved from http://www.eia.gov/forecasts/aeo/er/electricity_generation.cfm

Wenning, C.J. (2008). Dealing more effectively with alternative conceptions in science. Journal of Physics Teacher Education Online, 5(1), 11-19.

White, R.T. (1992). Implications of recent research on learning for curriculum and assessment. Journal of Curriculum Studies, 24, 153-164.

Weisser, D. (undated). A guide to life-cycle greenhouse gas $(G H G)$ emissions from electric supply Technologies. $\quad$ Retrieved on from http://www.iaea.org/OurWork/ST/NE/Pess/assets/GHG_manuscript_pre-print_versionDa nielWeisser.pdf.

Wilkenfield, G., Hamilton, C., \& Saddler, H. (2007). "Clean coal” and other greenhouse myths. Research Paper No. 49. The Australia Institute for a Just, Sustainable, Peaceful Future, August 2007.

Wimer, R.D., LaMori, P.N., \& Grant, A.A. (1977). Potential environmental issues related to geothermal power generation in Oregon. The ORE BIN, 39(5), 73-92. 
World Development Indicators database (2004) Electric power consumption > kWh (per capita) by country,

Retrieved

from http://www.NationMaster.com/graph/ene_ele_pow_con_kwh_percap-power-consumptio n-kwh-per-capita

World Development Indicators database (2006),Literacy rate, adult total > \% of people ages 15 and above by country, Retrieved from http://www.NationMaster.com/graph/edu_lit_rat_adu_tot_of_peo_age_15_and_abo-totalpeople-ages-15-above

World Nuclear Association. (2009). Radioactive wastes: Myths and realities. Retrieved from http://www.world-nuclear.org/info/inf103.html

Woolf, T., Takahashi, K., Keith, G., Roschelle, A.,. (2005). Feasibility Study of Alternative Energy and Advanced Energy Efficiency Technologies for Low-Income Housing in Massachusetts. Retrieved http://www.synapse-energy.com/Downloads/SynapseReport.2005-08.LEAN.Energy-Effi ciency-Technologies-for-Low-Income-Housing-in-MA.04-75.pdf

Yang F-Y., \& Anderson, O.R. (2003). Senior high school students' preference and reasoning modes about nuclear energy use. International Journal of Science Education, 25(2), 221244. 


\section{Propositional statements}

Sources of alternative energy

PS1. The source of geothermal energy is the heat stored in rocks by the earth's natural heat flow from the earth's core.

PS2. The application of heat from geothermal energy required several more meters into the Earth's crust since the shallow geothermal reservoirs may be as little as 100 metres below the earth's surface.

PS3. Hydrogen fuel cells are storage batteries for energy derived from other sources such as fossil fuel or solar energy and wind energy. ${ }^{2}$

PS4. Fuel cells are not a new source of energy, only a new method of using existing energy supplies. ${ }^{2}$. PS5. Nuclear energy utilises uranium-235 as a source which is usually mined using open cut or underground techniques. ${ }^{3}$

PS6. Uranium-235 is also only a small part of the total amount of uranium present in the earth. ${ }^{3}$ PS7. Nuclear energy utilises uranium which constitutes less than $1 \%$ of the natural uranium available in the world. ${ }^{1 \& 3}$

PS8. Uranium undergoes nuclear reaction called nuclear fission (the breaking of heavy nucleus into two or more smaller particles) which release huge amount of energy. ${ }^{1}$

PS9. Heat released in nuclear fission boils water into steam and turns a turbine to run a generator to produce electricity. $3 \& 4$

PS10. The amount of uranium used in the power plant is not adequate enough to cause atomic or nuclear explosions. ${ }^{5}$

PS11. The explosions that could occur are from the pressure caused by the production of hydrogen which is mixed with oxygen within the container for the reactors.

Energy conversion in generating electricity

PS12. The energy conversion of uranium in nuclear power is chemical to heat to kinetic to electrical. $6 \& 7$ PS13. Energy from the sun's light and sun's heat can be used to generate electricity. 8,9 \& 10

PS14. Solar-thermal technologies concentrate the sun's rays with mirrors or other reflective devices to heat a liquid to create steam, which is then used to turn a generator and create electricity. $9 \& 11$

PS15. The energy conversion in solar thermal energy is heat radiation from the sun to kinetic to electrical.

PS16. The efficiency of power plants to convert available energy into electricity of hydropower, geothermal, solar $\mathrm{PV}$, wind energy and ocean thermal energy are $90 \%, 16 \%, 15 \%-25 \%, 59 \%$ and $3 \%$ respectively. $1,4,12 \& 13$

PS17. Renewable energy add some much-needed flexibility to the energy resource mix by decreasing dependence on limited reserves of fossil fuels.

PS18. Photovoltaics convert light energy directly into an electric current that can either be used immediately or stored, such as in a battery, for later use. ${ }^{10}$

PS19. Cold temperature decreases resistance and increases voltage of the photovoltaic modules, thus lower voltage rating modules are ideal. ${ }^{10}$

PS20. How well the solar power system performs is dependent on the orientation of the PV solar panels and where it is manufactured and how the array is configured. ${ }^{17}$

PS 21. Power generation from hydropower depends on two factors, that is the head and the flow rate.

PS22. Head is defined as the vertical distance the water will fall through the turbine, and flow rate is how much water runs through the system. ${ }^{18}$

PS23. Most small-scale hydro systems require little or no reservoir to power the turbines, and the water will run straight through the generator and back into the stream.

Greenhouse gas emissions

PS24. Carbon dioxide is emitted when hydrogen is produced by steam reforming of methane in hydrogen fuel cell, which emits the highest GHG emission during its full life cycle.

PS25. Carbon dioxide is emitted during mining, processing of fuel and waste, transportation of raw materials, construction, dismantling, as well as generation of energy. ${ }^{20}$

PS26. Life cycle of any energy generation includes fuel exploration, mining, fuel transport, waste management and disposal, as well as power generation; all of these may emit GHG.

PS27. Renewable energy emitted a less amount of GHG compared to the conventional electrical energy production. ${ }^{21}$ 
PS28. About $5.7 \mathrm{gCeq} / \mathrm{kWh}$ is emitted by nuclear energy, whereas $275 \mathrm{gCeq} / \mathrm{kWh}$ and 215 $\mathrm{gCeq} / \mathrm{kWh}$ is emitted for coal and oil electricity generation.

PS29. Solar energy emits GHG through the production of solar cells (fabrication process), transportation of modules, installation, wiring and disposal of the module.

PS30. Geothermal plant has the least emission of $\mathrm{CO}_{2}$ compared to petroleum and natural gas with the same electrical output.

PS31. Biomass power generation releases more GHG compared to solar, wind and hydropower.

PS32. Palm oil derived from rainforest and peatlands generate more GHG emission than conventional diesel. ${ }^{23}$

PS33. Palm oil derived from existing plantations as a biofuel generate less GHG emission than conventional diesel. ${ }^{23}$

Cost (electricity and consumption)

PS34. Nuclear energy has the cheapest cost of electricity generated as the cost is accounted only for generation of electricity from raw materials.

PS35. Remediation of waste is not accounted for presently for alternative energy from all sources. ${ }^{24}$ PS36. Solar photovoltaic energy has the most expensive cost of electricity generated. ${ }^{13}$

PS37. The most expensive capital cost of construction for alternative energy is solar PV and the cheapest is hydropower.

PS38. The highest energy payback ratio for alternative energy is hydropower and the least is fuel cell. $^{26}$

Advantages and disadvantages

PS39. Biomass energy harnessed from plantation has the largest land requirement for energy production compared to hydropower, nuclear, wind and solar energy.

PS40. The high temperature radioactive wastewater from nuclear energy plants can cause ecological and mutation effect to marine life, such as fish. ${ }^{30}$

PS41. There are studies that have contradicted this. ${ }^{31}$

PS42. Residents living around a nuclear plant have a higher probability of getting cancer and giving birth to handicapped babies. ${ }^{30}$

PS43. Wind power plants produce noise up to only 300 metres and the sound level is about 40 $\mathrm{dB}$, which is an acceptable sound level in any countries. ${ }^{32}$

PS44. Wind turbines do not kill a lot of birds but do kill less than two birds per turbine per year. ${ }^{32}$ PS45. The wind mill must be placed away from the migration path of the birds. ${ }^{32}$

PS46. The amount of birds being killed is not alarming as it is less compared to the threat of other infrastructures. ${ }^{32}$

PS47. High level of nuclear radioactive waste is very dangerous as it lasts for thousands of years before decaying to safe levels. ${ }^{24}$

${ }^{1}$ Breeze (2005); ${ }^{2}$ Romm (2004); ${ }^{3}$ Cowan \& Adler (1976); ${ }^{4}$ Boyle (1996); ${ }^{5}$ Oehmen $(2011) ;{ }^{6}$ Loo \& Loo (2007); ${ }^{7}$ Duncan \& Kennett (2009); ${ }^{8}$ Komp (1995); ${ }^{9}$ Ricker (2008); ${ }^{10}$ Energy Alternatives (2007); ${ }^{11}$ Sklar \& Sheinkopf (1991); ${ }^{12}$ Masutani \& Takahashi (2001); ${ }^{13}$ Evans, Strezov \& Evans (2009); ${ }^{14}$ Wilkenfield, Hamilton \& Saddler (2007); ${ }^{15}$ Needham (2008); ${ }^{16}$ Diesendorf (2010); ${ }^{17}$ Ueda, Kurokawa, Kitamura, Yokota, Akanuma, \& Sugihara (2009); ${ }^{18}$ Baird (1994); ${ }^{19}$ Moreira \& Poole (1993); ${ }^{20}$ Spadaro, Langlois \& Hamilton (2000); ${ }^{21}$ Morgil, Secken \& Yucel, Ozyalcin-Oskay, Yavuz, \& Ural (2006); ${ }^{22}$ Lu \& Yang (2010); ${ }^{23}$ Danielsen et al. (2008); ${ }^{24}$ World Nuclear Association (2009); ${ }^{25}$ EIA (2010); ${ }^{26}$ Woolf, Takahashi, Keith, \& Roschelle (2005); ${ }^{27}$ EIA (2009); ${ }^{28}$ McDonald, Fargione, Kiesecker, Miller, \& Powell (2009); ${ }^{29}$ Melillo et al. (2009); ${ }^{30}$ Yang \& Anderson (2003); ${ }^{31}$ Nussbaum (2009); ${ }^{32}$ Mathew (2006); ${ }^{33}$ National Research Council (2007)

Figure 1. Propositional statements representing alternative energy used in this study 
An item in draft one of instrument

8. Which of the following is non renewable energy?

A. Wind

B. Geothermal

C. Nuclear

D. None of the above

An item in draft two of instrument

5. Which of these alternative sources of energy make use of materials that cannot be renewed?

A. Wind energy, hydropower, wave energy

B. Nuclear energy, solar energy, hydrogen fuel cell

C. Geothermal, tidal energy and ocean thermal energy

D. Only nuclear energy

Reason/s for your answer:

Figure 2. Examples of items in drafts one and two of the instrument developed. 
Example of item about Sources of alternative energy:

3. Which of the following statement is true about the source of nuclear energy, Uranium?
A. It is found in pure form in the ground.
B. It is renewable and there is plenty available.
C. It is cheaply obtainable.
D. It is non-renewable with little uranium available.
E. I don't know.

The reason for my answer is:

i. Pure uranium is obtained directly from the earth.

ii. There is very little uranium in the earth that can be used in a nuclear energy reactor. *

iii. There is plenty of uranium for use in a nuclear reactor.

iv. Please state your own reason:

Example of item about Conversion of energy in generating electricity

5. Currently nuclear energy in electricity The reason for my answer is: generation is produced in a process called:
A. Nuclear Fusion.
B. Nuclear Explosion.
C. Nuclear Fission.
D. None of the above.
E. I don't know.

i. The masses of the uranium used are combined and converted into energy via nuclear fusion.

ii. The uranium undergoes nuclear fission which breaks it into particles and releases a lot of energy.

iii. The uranium undergoes nuclear explosion which releases a lot of energy.

iv. Please state your own reason:

Example of item about Greenhouse gas emission

9. In which of the following processes are greenhouse gases emitted?
A. Mining, processing and transportation of raw materials.
B. Construction and decommissioning of power plants.
C. Generation of electrical power
D. All of the above. :
E. I don't know.

The reason for my answer is:

i. These processes produce acidic gases.

ii. The processes involve use of carbon based energy.

iii. Smoke is released.

iv. Please state your own reason

Figure 3. Examples of items from "What do you know about alternative energy?" 


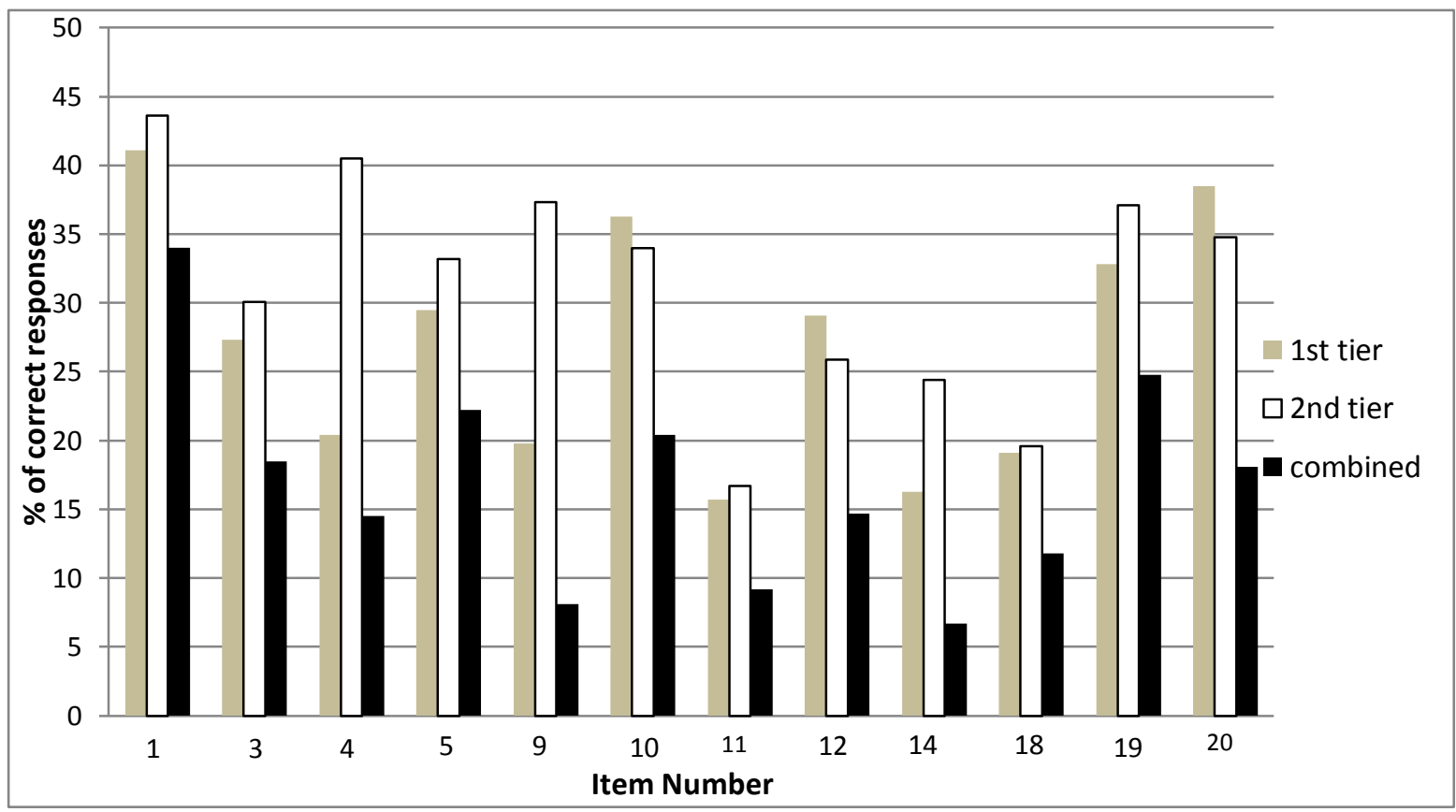

Figure 4 Year 10-11 students correct responses (\%) for the $1^{\text {st }}$ and $2^{\text {nd }}$ tier and combination ( $1^{\text {st }}$ and $2^{\text {nd }}$ tier) for the "What do you know about alternative energy?" instrument. 
Table 1 Alternative conceptions of alternative energy found from literature

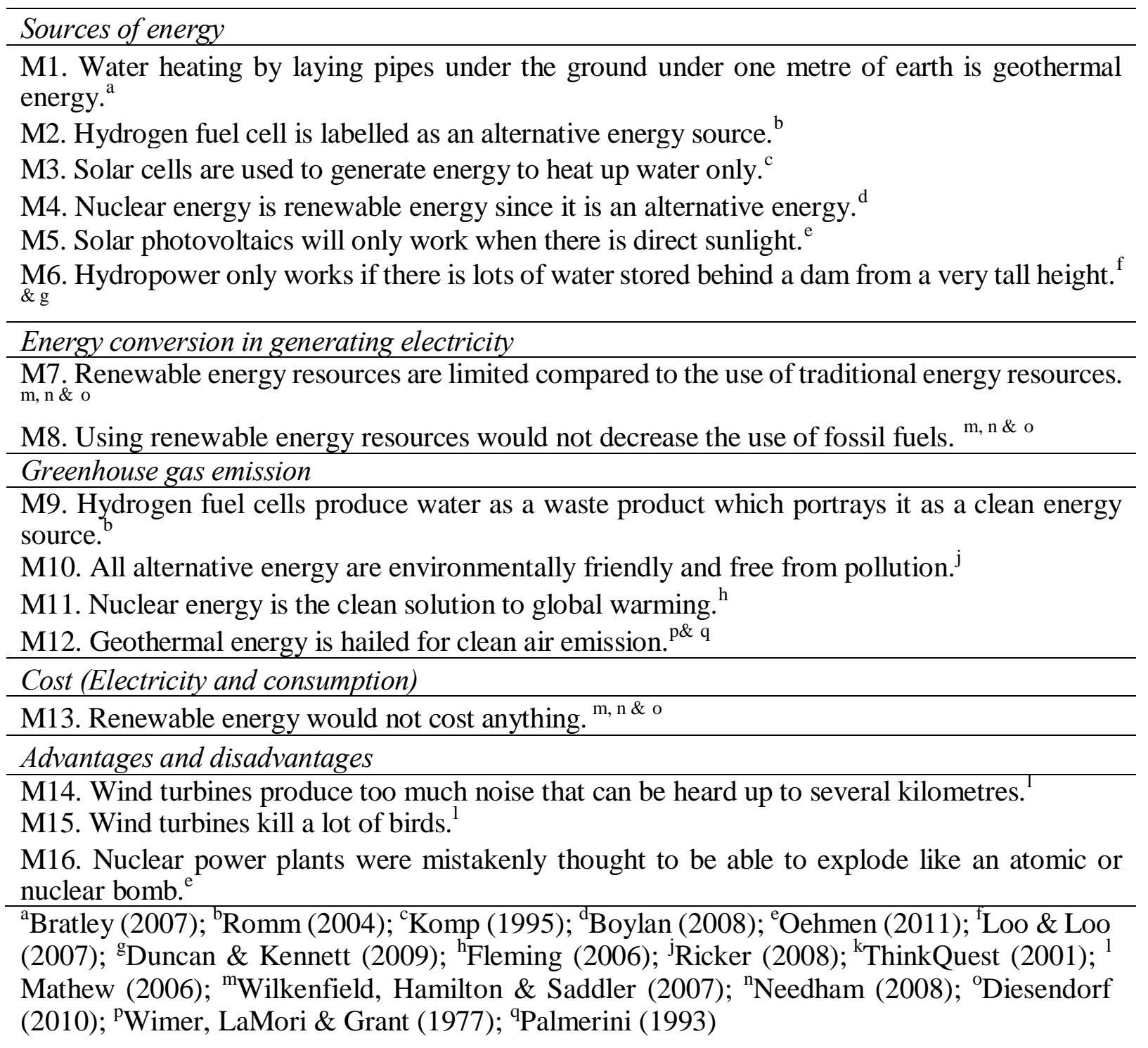


Table 2. Comparison of curriculum content between AAAS strand maps and Brunei syllabus for alternative energy

United States AAAS Strand Map for Energy Resources (NSDL, 2014)

Strand: Resources Grade range: $6-8$

Some resources are not renewable or renew very slowly. Fuels already accumulated in the earth, for instance, will become more difficult to obtain as the most readily available resources run out. How long the resources will last, however, is difficult to predict. The ultimate limit may be the prohibitive cost of obtaining them.

Energy from the sun (and the wind and water energy derived from it) is available indefinitely. Because the transfer of energy from these resources is weak and variable, systems are needed to collect and concentrate the energy.

Strand: Efficient use_Grade range: 9 - 12 The useful energy output of a device--that is, what energy is available for further change--is always less than the energy input, with the difference usually appearing as thermal energy. One goal in the design of such devices is to make them as efficient as possible--that is, to maximize the useful output for a given input.

Strand: Societal and environmental implications Grade range: $9-12$

When selecting fuels, it is important to consider the relative advantages and disadvantages of each fuel.

Industrialization brings an increased demand for and use of energy. Such usage contributes to having many more goods and services in the industrially developing nations but also leads to more rapid depletion of the earth's energy resources and to environmental risks associated with some energy resources. Nuclear reactions release energy without the combustion products of burning fuels, but the radioactivity of fuels and their by-products poses other risks.

Strand: Societal and environmental implications Grade range: $6-8$ Different ways of obtaining, transforming, and distributing energy have different environmental consequences.
Brunei Syllabus in Science for Alternative energy (UCLE, 2007 a, b, c, 2010)

(Year 10 and 11)

Describe metal ores as a finite resource

Solar, hydropower, nuclear, geothermal, wind, and chemical energy as sources of energy; Ocean and biomass energy not mentioned.

\section{(Year 10 and 11)}

Calculating the efficiency of an energy conversion their common use particularly in electrical output

(Year 10 and 11)

Discussion of the social, economic and environmental advantages and disadvantages of recycling metals as well as the environmental issues associated with power generation in general. 
Table 3. Summary of the concepts category, propositional knowledge statements and item numbers in "What do you know about alternative energy?"

\begin{tabular}{|c|c|c|c|}
\hline Concepts category & $\begin{array}{l}\text { Propositional } \\
\text { knowledge }\end{array}$ & $\begin{array}{l}\text { Original } \\
20 \text { items } \\
\text { test no. }\end{array}$ & $\begin{array}{l}\text { Final } 12 \text { item } \\
\text { test no }\end{array}$ \\
\hline Sources of alternative energy & PS1-PS11 & $1-5$ & $1,3,4,5$ \\
\hline $\begin{array}{l}\text { Conversion of energy in generating } \\
\text { electricity and efficiency }\end{array}$ & PS12-PS23 & $6-8$ & 0 \\
\hline Greenhouse gas emission & PS24-PS33 & $9-12$ & $9,10,11,12$ \\
\hline Cost (electricity and construction) & PS34-PS38 & $13-14$ & 14 \\
\hline Advantages and disadvantages & PS39-PS47 & $15-20$ & $18,19,20$ \\
\hline
\end{tabular}


Table 4. Test statistics for the administration of the revised 12 items "What do you know about alternative energy?" instrument $(n=491)$

No. of items

Deleted items 2, 6, 7, 8, 13,

$15,16 \& 17$

Total mean score $(S D)$

$7.03(3.90)$

Max scores possible

24

Cronbach's coefficient alpha $(\alpha)$

0.61

No. of items with reading >Year 103

grade levels

Year 7-10 9 
Table 5. Year 10-11 students' alternative conceptions of alternative energy from the revised

"What do you know about alternative energy?" instrument

\begin{tabular}{|c|c|c|}
\hline Alternative conceptions & $\begin{array}{l}\text { Choice } \\
\text { combination }\end{array}$ & $\begin{array}{l}\% \text { of } \\
\text { students }\end{array}$ \\
\hline \multicolumn{3}{|l|}{ Sources of energy } \\
\hline 1. Solar energy obtained from interior of the earth: & $1 \mathrm{~A}$ & 40 \\
\hline as heat necessarily comes from the sun & 1Aii & 32 \\
\hline 2. Uranium is found in pure form in the ground: & $3 \mathrm{~A}$ & 25 \\
\hline as pure uranium is obtained directly from the earth & $3 \mathrm{Ai}$ & 15 \\
\hline 3. Uranium is renewable and their availability is plenty & 3B & 12 \\
\hline $\begin{array}{l}\text { 4. In hydrogen fuel cell, the production of hydrogen does not produce greenhouse } \\
\text { gases }\end{array}$ & $4 \mathrm{~A}$ & 38 \\
\hline $\begin{array}{l}\text { 5. Hydrogen fuel cell is considered 'clean' as hydrogen is the only by-product } \\
\text { Conversion of energy }\end{array}$ & 4B & 15 \\
\hline \multirow{2}{*}{$\begin{array}{l}\text { 6. Nuclear energy is produced in a process called nuclear fusion where: } \\
\text { the uranium used are combined and converted into energy via nuclear fusion }\end{array}$} & $5 \mathrm{~A}$ & 26 \\
\hline & $5 \mathrm{Ai}$ & 18 \\
\hline 7. Nuclear energy is produced in a process called nuclear explosion & $5 \mathrm{~B}$ & 20 \\
\hline \multicolumn{3}{|l|}{ Greenhouse gas emission } \\
\hline $\begin{array}{l}\text { 8. Greenhouse gases are emitted during mining, processing and transportation } \\
\text { of raw materials only }\end{array}$ & $9 \mathrm{~A}$ & 22 \\
\hline $\begin{array}{l}\text { 9. Greenhouse gases are emitted during construction and decommissioning of } \\
\text { power plants only }\end{array}$ & 9B & 28 \\
\hline 10. Greenhouse gases are emitted during the generation of electrical power only & $9 \mathrm{C}$ & 18 \\
\hline 11. No alternative sources of energy contribute to global warming & $10 \mathrm{~A}$ & 17 \\
\hline 12. Only hydrogen fuel cell source of energy contribute to global warming & $10 \mathrm{~B}$ & 11 \\
\hline $\begin{array}{l}\text { 13. All alternative sources of energy contribute to global warming in the same } \\
\text { proportions as fossil fuel sources of energy }\end{array}$ & $10 \mathrm{D}$ & 13 \\
\hline $\begin{array}{l}\text { 14. Nuclear energy emits the most greenhouse gases during the whole life cycle } \\
\text { starting from its source to generation of electricity }\end{array}$ & $11 \mathrm{~A}$ & 35 \\
\hline $\begin{array}{l}\text { 15. Solar power energy emits the most greenhouse gases during the whole } \\
\text { life cycle starting from its source to generation of electricity }\end{array}$ & $11 \mathrm{C}$ & 17 \\
\hline $\begin{array}{l}\text { 16. Biodiesels are used to replace diesel because all biodiesels emit less } \\
\text { greenhouse gases: }\end{array}$ & $12 \mathrm{C}$ & 29 \\
\hline as all biodiesel contain less carbon molecules compared to diesel. & 12Cii & 23 \\
\hline \multicolumn{3}{|l|}{ Cost (electricity and construction) } \\
\hline 17. The highest cost for the construction of power plant is hydropower: & $14 \mathrm{C}$ & 43 \\
\hline as it requires a large dam to be built & 14Ciii & 25 \\
\hline 18. The highest cost for the construction of power plants is tidal power & 14D & 13 \\
\hline \multicolumn{3}{|l|}{ Advantages and disadvantages } \\
\hline 19. Wind energy does not kill birds or cause noise pollution & $18 \mathrm{~A} / 18 \mathrm{~B}$ & $34 / 14$ \\
\hline $\begin{array}{l}\text { 20. Wind energy does not kill birds or cause noise pollution, or can only be } \\
\text { located on-shore. }\end{array}$ & $18 \mathrm{D}$ & 20 \\
\hline $\begin{array}{l}\text { 21. Solar energy competes with humans for food in order to obtain the raw } \\
\text { materials needed as: the sun is the main source of energy for most organisms }\end{array}$ & 19Bii & 24 \\
\hline $\begin{array}{l}\text { 22. Ocean thermal energy competes with humans for food in order to obtain } \\
\text { the raw materials needed }\end{array}$ & $19 \mathrm{C}$ & 15 \\
\hline 23. Waste from fuel cells cannot be disposed of safely as it requires hundreds of & $20 \mathrm{I}$ & 16 \\
\hline
\end{tabular}

Note: Numbers and letters (capital and small i or ii) under the headings "Choice combination" refers to items. e.g 1. 1Aii refers to Item no 1; Part A of content part of first tier of item and Choice ii of reason part of the second tier of item.

e.g 2. 14Ciii refers to Item no 14; Part C of content part of first tier of item and Choice iii of reason part of the second tier of item. 